\title{
Mass-balance characteristics of arctic glaciers
}

\author{
Roger J. BRAITHWAITE \\ School of Environment and Development, University of Manchester, Manchester M13 9PL, UK \\ E-mail: r.braithwaite@man.ac.uk
}

\begin{abstract}
A survey of available mass-balance data shows that glaciers on arctic islands, i.e. mountain glaciers and ice caps in northern Canada, Greenland, Svalbard and the Eurasian islands, share massbalance characteristics of low annual amplitude and small interannual variability. By contrast, glaciers around the Arctic (e.g. in Alaska, Iceland, mainland Scandinavia and northern Eurasia) can have exceptionally large annual amplitude and interannual variability but otherwise share characteristics with glaciers in lower latitudes. The arctic island glaciers occur in areas with low annual precipitation and high annual temperature variability, i.e. in dry-cold or continental regions. Most glaciers surrounding the Arctic (Alaska, Iceland and Scandinavia) occur in areas with high annual precipitation and low annual temperature variability, i.e. in wet-warm or maritime regions. Earlier mass-balance modelling showed that arctic island glaciers have low sensitivity to temperature changes consistent with their low mass-balance amplitude. However, very large changes in mass balance could occur on arctic island glaciers if the sea ice surrounding the arctic islands were reduced so that the climate of the arctic islands becomes more maritime.
\end{abstract}

\section{INTRODUCTION}

To the casual observer, all glaciers should be 'arctic' as they all consist of snow and ice and only survive in relatively low temperatures. However, I will demonstrate that some glaciers are more arctic than others are and that glaciers on the arctic islands of North America and Eurasia have distinct massbalance characteristics compared with glaciers around the Arctic. This is not just a question of taxonomy, as the arctic islands carry such large glacier areas that they could dominate the response of the global cryosphere to climate change. Furthermore, if we want to develop new ways of monitoring arctic glaciers we must understand their behaviour better. For example, the mass-balance forcing of surface-elevation changes depends upon the standard deviation of the mass balance (Braithwaite, 1994), which is itself a climatological characteristic (Braithwaite and Zhang, 1999).

There is no clear definition of an 'arctic glacier', although the term implies location in the arctic geographical region. The concept has a recent social construction. The International Arctic Science Committee set up a Working Group on Arctic Glaciology in 1992, and the activities of this group included analysis of observation from glaciers in Alaska, Iceland, Scandinavia and mainland Russia, as well as glaciers on the arctic islands (see map in fig. 1.1 in Jania and Hagen, 1996). This implies a broad understanding of 'arctic glacier', but most glaciers in Alaska and Scandinavia, and all Icelandic glaciers, actually lie south of the Arctic Circle. In the 1930s and 1940s, H.W. Ahlmann and P.A. Shumskii developed glacier classifications that show how glaciers exist over a wide range of climatic conditions. Ahlmann (1948) classed glaciers as polar, subpolar and temperate. His concepts of polar and subpolar glaciers were informed by Koch and Wegener's work in Greenland (1912-13) and his own work in Nordaustlandet, Svalbard, in 1931 (Ahlmann, 1948) and we may suppose that subpolar glaciers in Ahlmann's classification do occur on arctic islands, especially as an earlier version of Ahlmann's classification refers to 'sub-arctic'. A subpolar glacier is one where summer melting occurs at the surface but the interior of the glacier is below the freezing temperature (Ahlmann, 1948), which is a sure recipe for refreezing of meltwater as it percolates into the cold underlying strata to form superimposed ice (Koerner, 1970) or ice layers (Braithwaite and others, 1994). However, some refreezing and internal accumulation occurs on most glaciers (Hughes and Seligman, 1939; Markl and Wagner, 1978; Trabant and Mayo, 1985), so there is no direct link between meltwater refreezing and 'arctic' in a geographical sense, and Ahlmann's 'subpolar' class does not necessarily refer to the Polar Regions either. Significant refreezing of meltwater can occur on any glacier with annual air temperature below -6 to $-8^{\circ} \mathrm{C}$ (Huang, 1990; Braithwaite and others, 2002).

'The zones of ice formation' concept, developed by Shumskii in the 1940s but published later (Shumskii, 1964), avoids any association between classification and geography. Shumskii's 'infiltration zones' can occur both on arctic islands and in very high mountain ranges (see Shumskii, 1964, ch. 20). Our modern concept of glacier zones (Paterson, 1994, fig. 3.1) rests mainly on work in Greenland (Benson, 1961) and on arctic islands (Baird, 1952; Müller, 1962) but, again, avoids any geographical association, as does our modern temperature classification of glaciers (Paterson, 1994, p. 205).

\section{APPROACH}

My approach to the mass balance of arctic glaciers is an empirical one: I look at all available mass-balance data up to 1999 to see if there is any association between geographical location (e.g. glaciers lying in the Arctic) and mass-balance behaviour. I use the dataset of Braithwaite (2002) with many updates and corrections from Dyurgerov (2002) to give 302 glaciers for 1922-99, from all over the world, with measured mass balance for at least 1 year.

I set the scene by plotting mass-balance data (Fig. 1) for two greatly contrasting glaciers: the northwest sector of Devon Ice Cap, Arctic Canada, and Ålfotbreen, west Norway. There is almost an order-of-magnitude difference 


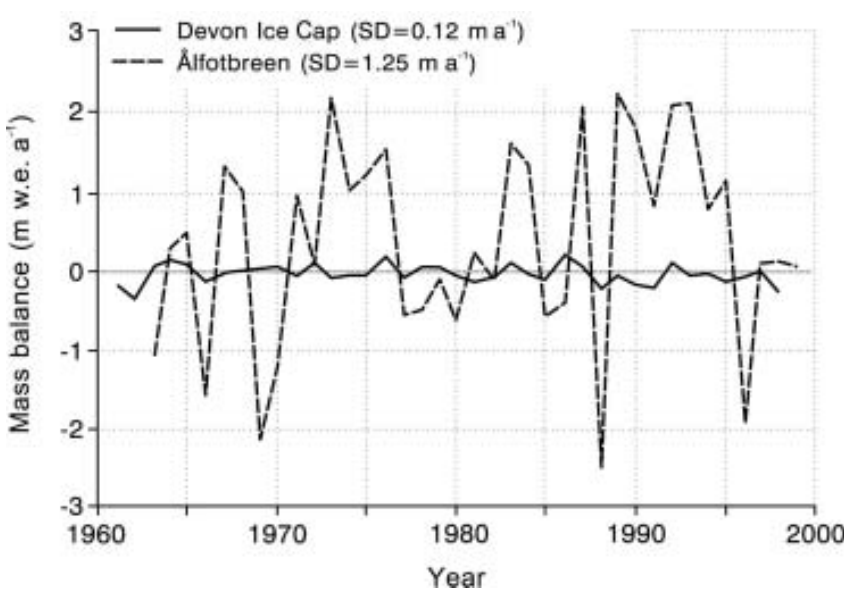

Fig. 1. The contrast in mass-balance variability between the northwest sector of Devon Ice Cap, Arctic Canada, and Ålfotbreen, west Norway.

in standard deviation for the mass balances of the two glaciers, although they are both 'arctic glaciers' according to Jania and Hagen (1996) or 'circum-arctic glaciers' according to Dowdeswell and others (1997). These large differences in interannual variability of glacier mass-balance series (Braithwaite and Zhang, 1999) are concealed when massbalance time series for different glaciers are published in uniform size, as in Dowdeswell and others (1997) and Nesje and Dahl (2000), rather than in uniform scale.

It is important to know the mass balances of individual glaciers, and regional (Dowdeswell and others, 1997) and global averages of mass balance (Dyurgerov and Meier, 1997; Cogley and Adams, 1998), but we must be careful about simple averages of data that are known to have 'complex spatial and temporal patterns' (Chappell and Agnew, 2004). Figure 1 demonstrates that mass balances for individual glaciers can vary from year to year in very different ways. The contrast in Figure 1 suggests the hypothesis that glaciers on arctic islands have different mass-balance characteristics to more southerly glaciers. (Note that the two glaciers in Figure 1 have very similar mean equilibrium-line altitudes.) Although rather arbitrary, to test the hypothesis it is convenient to split the southerly glaciers into two groups: glaciers immediately surrounding the Arctic (circum-arctic glaciers) and glaciers south of $60^{\circ} \mathrm{N}$. For the present study, the circum-arctic glaciers are those found in mainland North America north of $60^{\circ} \mathrm{N}$, in

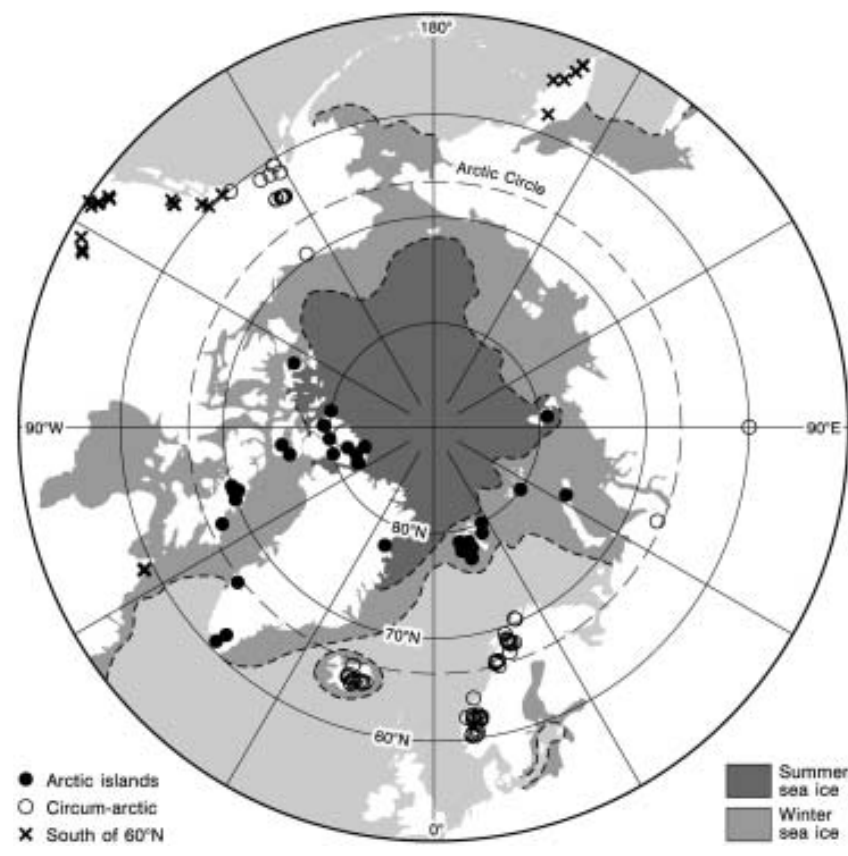

Fig. 2. Location of glaciers in and around the Arctic with measured mass balance according to Braithwaite (2002) and Dyurgerov (2002).

Iceland, Scandinavia and in northern Russia (Fig. 2; Table 1). The group of glaciers south of $60^{\circ} \mathrm{N}$ includes several tropical glaciers, but I exclude four glaciers in the Antarctic from the present study. The four data points in Figure 2 for Greenland refer to three local glaciers and one sector of the Greenland ice whose mass balance is determined from top to toe. We do not yet have a series of mass-balance measurements for the whole Greenland ice sheet considered as one large glacier.

\section{CLIMATIC SETTING}

Annual precipitation and annual temperature range are important climatological characteristics for glaciers. In classical climatology, high temperature range and low precipitation characterize continental climate, and low temperature range and high precipitation generally characterize maritime climate, although low temperature ranges occur in the tropics irrespective of precipitation (Visher, 1923a, b). Each point in Figure 3 represents a 0.5 latitude/ longitude grid square that contains a glacier with measured

Table 1. Glaciers with mass-balance data used in the present study, based on Braithwaite (2002) updated and corrected with data from Dyurgerov (2002)

\begin{tabular}{|c|c|c|c|}
\hline Main group & Sub-group & $\begin{array}{l}\text { Glaciers with } \\
\text { mass-balance data } \\
\text { for at least } 1 \text { year }\end{array}$ & $\begin{array}{l}\text { Glaciers with separate } \\
\text { winter and summer } \\
\text { balances and at least } \\
5 \text { years of record }\end{array}$ \\
\hline
\end{tabular}

Arctic islands

Circum-arctic

South of $60^{\circ} \mathrm{N}$ Antarctic

Total
Arctic Canada, Greenland, Svalbard and Arctic Russia

Mainland North America, Iceland, mainland Norway, Sweden and mainland Russia

Not used in this study

$\begin{array}{cc}48 & 22 \\ 75 & 41 \\ & \\ 175 & 58 \\ 4 & - \\ 302 & 121\end{array}$




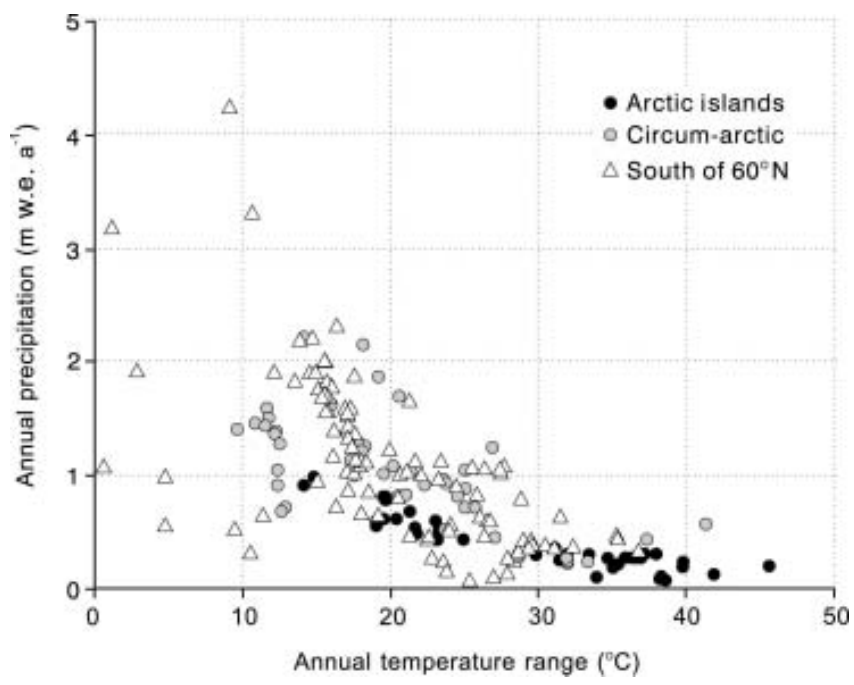

Fig. 3. Annual precipitation vs annual temperature range for $0.5^{\circ}$ latitude/longitude grid squares containing glaciers whose mass balance has been measured for at least 1 year. Climatological data taken from the gridded climatology of New and others (1999).

mass balance. The annual precipitation and annual temperature range are from the gridded climatology of New and others (1999) and refer to the mean altitude of topography within each grid square. The mean altitude of topography in the arctic islands is generally close to the mean glacier altitude, while the altitude difference can be up to several thousand metres for more southerly glaciers.

Annual temperature range is high and annual precipitation is low for grid squares with arctic island glaciers, which appear in two groups in Figure 3. The highest ranges $\left(30-45^{\circ} \mathrm{C}\right)$ and lowest precipitation $\left(<0.5 \mathrm{~m}\right.$ w.e. $\left.\mathrm{a}^{-1}\right)$ occur in the Canadian and Russian arctic islands, while Svalbard has a more moderate temperature range (around $15-25^{\circ} \mathrm{C}$ ) and annual precipitation up to $1 \mathrm{mw}$ w.e. $\mathrm{a}^{-1}$. The arctic islands obviously have extremely continental climate, but parts of Svalbard are less continental. Some glaciers south of $60^{\circ} \mathrm{N}$, in the high mountains of Asia, are also continental in climatic terms. Many circum-arctic glaciers are quite maritime, with low annual temperature range and high annual precipitation, but we must remember that there are also strong maritime/continental contrasts within this group of glaciers (e.g. between the coast and interior of Alaska (Østrem and others, 1981)).

\section{MASS-BALANCE VARIABILITY}

Figure 4 shows available data for winter and summer balances. The data points refer to mean values of massbalance series that are at least 5 years old, in the hope of avoiding artefacts due to short series measured around 'exceptional years'. The number of glaciers is therefore greatly reduced (Table 1 ) because winter and summer balances are not measured on all glaciers and because short mass-balance series predominate (Braithwaite, 2002; Dyurgerov, 2002). In particular, McCall Glacier in northern Alaska, which probably qualifies as a truly arctic glacier, falls out of further analysis because we do not have separate winter and summer balances. I will not discuss the one clear anomaly in Figure 4 (Ivory Glacier, New Zealand) but suspect that it may be an error. Aside from this anomaly, there is a

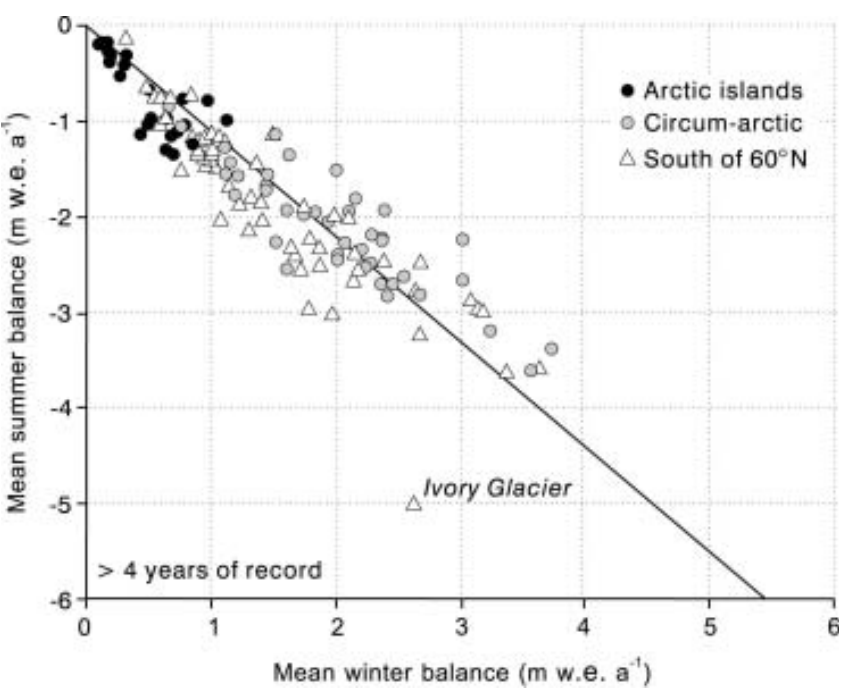

Fig. 4. Mean summer balance vs mean winter balance for glaciers with at least 5 years of record for both variables.

strong correlation between mean summer and mean winter balances. The difference between these quantities is the mean mass balance, and the deviation from a straight line reflects the effects of non-zero mass balance. Clearly, most of the glaciers have negative mass balance, but mass balance is generally the small difference between the two larger quantities. Arctic island glaciers have low values of winter and summer balance compared with some much larger values for circum-arctic glaciers. Some glaciers south of $60^{\circ} \mathrm{N}$ (e.g. in central Asia) also have low summer and winter balances due to their extreme continental climate. The low winter balances for arctic island glaciers partly reflect the low annual precipitation for these glaciers (Fig. 3) but also reflect the effects of meltwater refreezing whereby a glacier can exist with lower snow accumulation than it would need under the same temperature conditions without refreezing (Braithwaite and others, 2002).

Because of the strong correlation between winter and summer balance, several authors (Meier, 1984; Braithwaite and Zhang, 1999) choose to use the average of their magnitudes as a mass-balance characteristic. This is the mass-balance amplitude, which is close to the average winter balance and generally somewhat less than the annual accumulation. There are signs of secular variation in massbalance amplitude (Dyurgerov and Meier, 1999) but it is much less variable than annual or net balance and can be regarded as a quasi-constant characteristic, or parameter, of mass balance. The mean mass-balance amplitude in the arctic islands is much less than in the circum-arctic (Fig. 5), once again expressing the continental climate of the arctic island glaciers. However, within the arctic islands group, Svalbard glaciers have higher mass-balance amplitude than glaciers in the Canadian and Russian arctic islands.

The interannual variability of mass-balance series (e.g. as expressed by the standard deviation) is strongly controlled by the mass-balance amplitude according to Braithwaite and Zhang (1999). I update these earlier results in Figure 6 using glaciers with at least 5 years of record. The length of record to use for such graphs is a judgement call: choice of a longer record reduces the number of points but improves the correlation. I have also chosen to 'force' the regression line through the origin because this makes more sense physically 


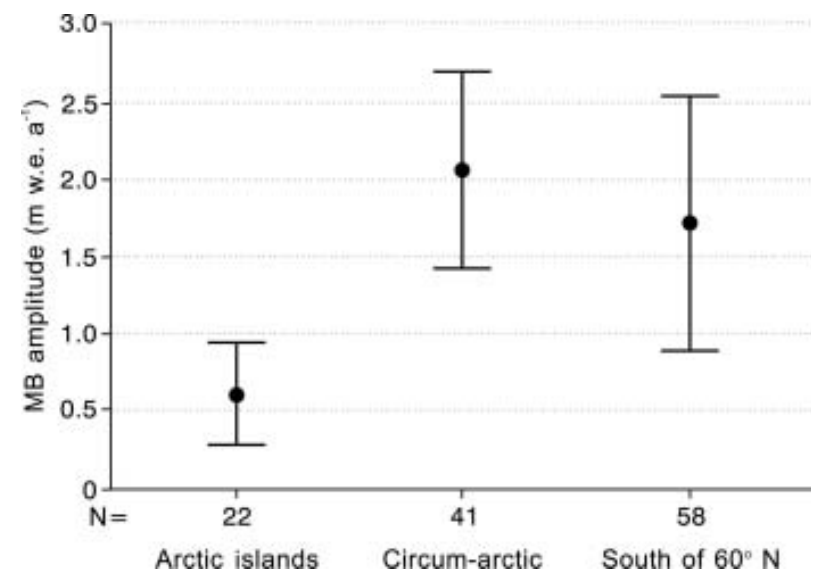

Fig. 5. Mean and standard deviation of mass-balance amplitude for 121 glaciers divided into three classes: Arctic islands, circum-arctic and south of $60^{\circ} \mathrm{N}$.

than the simple regression of Braithwaite and Zhang (1999). Arctic island glaciers have low interannual variability and low mass-balance amplitude, while circum-arctic glaciers generally have high variability and high amplitude. Once again, high mountain glaciers south of $60^{\circ} \mathrm{N}$ can have similar characteristics to glaciers on arctic islands. Aside from the climatic setting, the standard deviation of mass balance may also depend upon glacier size by analogy with meteorological variables whose anomalies become smaller when the average is taken over a larger area (personal communication from J. Oerlemans, 2004).

The average annual accumulation over the Greenland ice sheet is about $0.3 \mathrm{~m}$ w.e. $\mathrm{a}^{-1}$ (Ohmura and Reeh, 1991). For this value of mass-balance amplitude, the regression line in Figure 6 gives an estimated standard deviation of about $0.1 \mathrm{~m}$ w.e. $\mathrm{a}^{-1}$ for the average mass balance of the Greenland ice sheet. Although this indicates a relatively low interannual variability for mass balance compared with other glaciers, it may explain apparent contradictions in shortterm measurements of thickness change (Zwally and others, 1989; Braithwaite, 1994; Van der Veen, 2001).

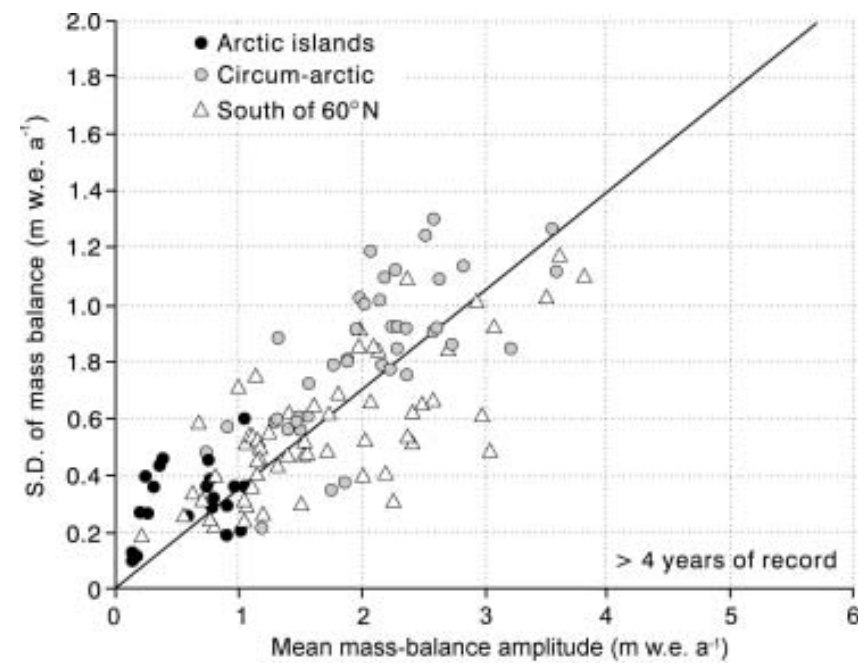

Fig. 6. Standard deviation (S.D.) of mass-balance time series vs the mean mass-balance amplitude for glaciers with at least 5 years of mass-balance record. The straight line is a regression line forced through the origin.

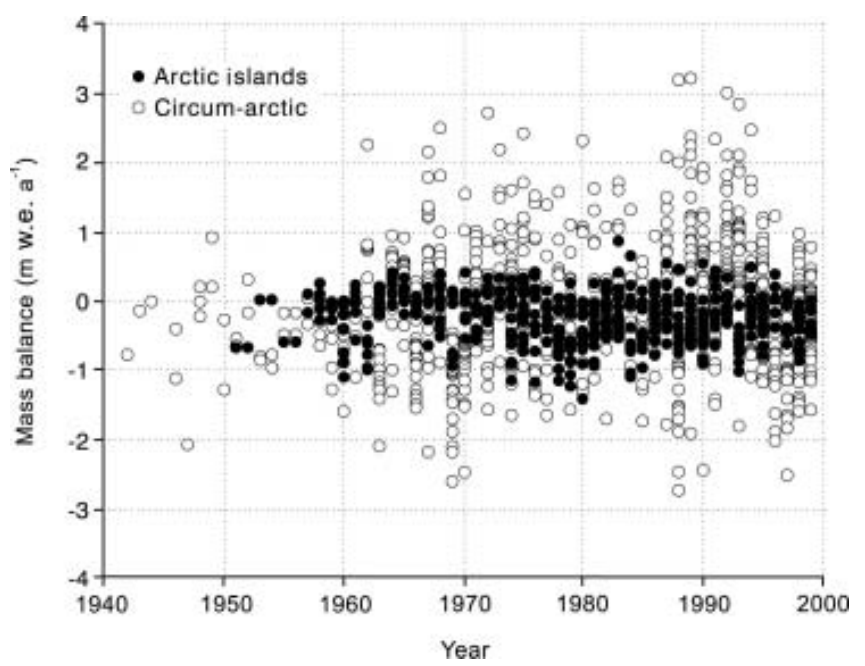

Fig. 7. Mass balance vs year for all available mass-balance data from arctic island and circum-arctic glaciers.

Figure 7 is an update of figure 4.1 in Jania and Hagen (1996) that graphed all available data from what those authors termed 'arctic glaciers'. In this graph, I distinguish between glaciers on arctic islands and glaciers in the circumarctic. There is obviously a large amount of scatter, reflecting the importance of year-to-year fluctuations in mass balance. Leaving aside the criticism that such graphs are based on a fluctuating number of measurements in each year, it is clear that the mass balance of arctic island glaciers is much less variable than that of the circum-arctic glaciers. There is no sign of any trend of increasing or decreasing mass balance up to 1999 , which we would have to detect against the background of year-to-year fluctuations. The impression of a greater range of variation at the end of series is due to the start of new measurements in the 1990s on Icelandic glaciers with large accumulation and mass-balance amplitude.

\section{EFFECTS OF CLIMATE CHANGE}

Oerlemans and Fortuin (1992), Braithwaite and others (2002) and de Woul and Hock (2005) use glacier-climate models to calculate the hypothetical change in mass balance due to a $1^{\circ} \mathrm{C}$ temperature increase. The resulting temperature sensitivity for mass balance depends on precipitation regime (Oerlemans and Fortuin, 1992; de Woul and Hock, 2005) or mass-balance amplitude (Braithwaite and others, 2002). The glaciers of the arctic islands have low precipitation, low mass-balance amplitude and thereby low temperature sensitivity. The latter fits well with the low variability (standard deviation) of mass balance as the glaciers are making their own temperature sensitivity experiment every year. Even with increased temperature (e.g. due to global warming) in the immediate neighbourhood of the glacier, the negative mass balance of an arctic island glacier cannot be very high and cannot increase by much. Arctic island glaciers cover a vast area (Dowdeswell and Hagen, 2004), but a relatively small negative mass balance over a large area will only cause moderate sea-level rise. The small variations in mass balance of arctic island glaciers are due to low annual precipitation and high annual temperature range, but we should re-examine Figure 3 and ask ourselves why the arctic islands have such a climate.

The climate of the arctic islands, as represented by annual precipitation and temperature range in Figure 3, is 
dominated by the effects of sea ice that ensure low temperature in winter and reduced summer temperatures compared with Alaska, Iceland and mainland Scandinavia which are readily accessible to extratropical cyclones and warm sea surface temperatures. The low precipitation in the arctic islands reflects the generally low temperatures and the distance from moisture sources. The strong gradient in accumulation across Devon Ice Cap (Koerner, 1966) is a good example of how a local moisture source (the North Water' polynya in northern Baffin Bay) might enhance the accumulation. However, a bigger change of climate in the Arctic could occur if slightly higher summer temperatures melted the sea ice, thereby increasing winter temperatures and reducing the annual temperature range in Figure 3, to allow greater access of extratropical cyclones and an increase in precipitation. The glaciers of the arctic islands might then show greater mass-balance variability and sensitivity to climate change like glaciers around the Arctic. We need more work on arctic glaciers to assess the likelihood of this scenario.

\section{ACKNOWLEDGEMENTS}

The ARCICE programme of the UK Natural Environment Research Council did not support this work. This study uses mass-balance data that many individual scientists and organizations collected and made freely available for further study and analysis. The International Arctic Science Committee has done an especially good job in encouraging workers to publish previously unavailable data from glaciers in and around the Arctic. J. Oerlemans was the Scientific Editor for this paper.

\section{REFERENCES}

Ahlmann, H.W. 1948. Glaciological research on the North Atlantic coasts. London, Royal Geographical Society.

Baird, P.D. 1952. The glaciological studies of the Baffin Island Expedition, 1950. Part I: Method of nourishment of the Barnes Ice Cap. J. Glaciol., 2(11), 2-9, 17-19.

Benson, C.S. 1961. Stratigraphic studies in the snow and firn of the Greenland ice sheet. Folia Geogr. Dan., 9, 13-37.

Braithwaite, R.J. 1994. Thoughts on monitoring the effects of climate change on the surface elevation of the Greenland ice sheet. Global Planet. Change, 9(3-4), 251-261.

Braithwaite, R.J. 2002. Glacier mass balance: the first 50 years of international monitoring. Prog. Phys. Geog., 26(1), 76-95.

Braithwaite, R.J. and Y. Zhang. 1999. Relationships between interannual variability of glacier mass balance and climate. J. Glaciol., 45(151), 456-462.

Braithwaite, R.J., M. Laternser and W.T. Pfeffer. 1994. Variations of near-surface firn density in the lower accumulation area of the Greenland ice sheet, Pâkitsoq, West Greenland. J. Glaciol., 40(136), 477-485.

Braithwaite, R.J., Y. Zhang and S.C.B. Raper. 2002. Temperature sensitivity of the mass balance of mountain glaciers and ice caps as a climatological characteristic. Z. Gletscherkd. Glazialgeol., 38(1), 35-61.

Chappell, A. and C.T. Agnew. 2004. Modelling climate change in West African Sahel rainfall (1931-90) as an artefact of changing station locations. Int. J. Climatol., 24, 547-554.

Cogley, J.G. and W.P. Adams. 1998. Mass balance of glaciers other than the ice sheets. J. Glaciol., 44(147), 315-325.

De Woul, M. and R. Hock. 2005. Static mass-balance sensitivity of Arctic glaciers and ice caps using a degree-day approach. Ann. Glaciol., 42 (see paper in this volume).
Dowdeswell, J.A. and J.O. Hagen. 2004. Arctic glaciers and ice caps. In Bamber, J.L. and A.J. Payne, eds. Mass balance of the cryosphere: observations and modelling of contemporary and future changes. Cambridge, Cambridge University Press, 527-557.

Dowdeswell, J.A. and 10 others. 1997. The mass balance of circum-Arctic glaciers and recent climate change. Quat. Res., 48(1), 1-14.

Dyurgerov, M. 2002. Glacier mass balance and regime: data of measurements and analysis. INSTAAR Occasional Paper 55.

Dyurgerov, M.B. and M.F. Meier. 1997. Mass balance of mountain and subpolar glaciers: a new global assessment for 1961-1990. Arct. Alp. Res., 29(4), 379-391.

Dyurgerov, M.B. and M.F. Meier. 1999. Analysis of winter and summer glacier mass balances. Geogr. Ann., 81A(4), 541-554.

Huang, M. 1990. On the temperature distribution of glaciers in China. J. Glaciol., 36(123), 210-216.

Hughes, T.P. and G. Seligman. 1939. The temperature, melt water movement and density increase in the névé of an Alpine glacier. Mon. Not., R. Astron. Soc., Geophysical Supplement, 4(8), 616-647.

Jania, J. and J.O. Hagen. 1996. Mass balance of Arctic glaciers. Sosnowiec/Oslo, International Arctic Science Committee. Working Group on Arctic Glaciology. (IASC Report 5.)

Koerner, R.M. 1966. Accumulation on the Devon Island ice cap, Northwest Territories, Canada. J. Glaciol., 6(45), 383-392.

Koerner, R.M. 1970. Some observations on superimposition of ice on the Devon Island ice cap, N.W.T. Canada. Geogr. Ann., 52A(1), 57-67.

Markl, G. and H.P. Wagner. 1978. Messungen von Eis- und Firntemperaturen am Hintereisferner (Ötztaler Alpen). Z. Gletscherkd. Glazialgeol., 13(1-2), 261-265.

Meier, M.F. 1984. Contribution of small glaciers to global sea level. Science, 226(4681), 1418-1421.

Meier, M.F., M.B. Dyurgerov and G.J. McCabe. 2003. The health of glaciers: recent changes in glacier regime. Climatic Change, 59(1-2), 123-135.

Müller, F. 1962. Zonation in the accumulation area of the glaciers of Axel Heiberg Island, N.W.T., Canada. J. Glaciol., 4(33), 302-311.

Nesje, A. and S.O. Dahl. 2000. Glaciers and environmental change. London, Arnold.

New, M., M. Hulme and P. Jones. 1999. Representing twentieth century space-time climate variability. I. Development of a 1961-1990 mean monthly terrestrial climatology. J. Climate, 12(3), 829-856.

Oerlemans, J. and J.P.F. Fortuin. 1992. Sensitivity of glaciers and small ice caps to greenhouse warming. Science, 258(5079), 115-117.

Ohmura, A. and N. Reeh. 1991. New precipitation and accumulation maps for Greenland. J. Glaciol., 37(125), 140-148.

Østrem, G., N. Haakensen and T. Eriksson. 1981. The glaciation level in southern Alaska. Geogr. Ann., A63(3-4), 251-260.

Paterson, W.S.B. 1994. The physics of glaciers. Third edition. Oxford, etc., Elsevier.

Shumskii, P.A. 1964. Principles of structural glaciology. New York, Dover Publications.

Trabant, D.C. and L.R. Mayo. 1985. Estimation and effects of internal accumulation on five glaciers in Alaska. Ann. Glaciol., 6. 113-117.

Van der Veen, C.J. 2001. Greenland ice sheet response to external forcing. J. Geophys. Res., 106(D24), 34,047-34,058.

Visher, S.S. 1923a. The laws of temperature. Ann. Assoc. Am. Geographers, 13(1), 15-40.

Visher, S.S. 1923b. The laws of winds and moisture. Ann. Assoc. Am. Geographers, 13(4), 169-207.

Zwally, H.J., A.C. Brenner, J.A. Major, R.A. Bindschadler and J.G. Marsh. 1989. Growth of Greenland ice sheet: measurement. Science, 246(4937), 1587-1589. 